\title{
ANALISA FAKTOR-FAKTOR YANG BERPENGARUH DALAM MENINGKATKAN KINERJA BISNIS \\ UKM BATIK MADURA
}

\author{
Fathor.AS
}

Fakultas Ekonomi dan Bisnis

Universitas Trunojoyo Madura

\begin{abstract}
ABSTRAK
Tujuan penelitian ini adalah untuk menganalisis faktor-faktor yang berpengaruh terhadap kinerja bisnis UKM batik Madura. Penelitian ini menggunakan pendekatan kuantitatif dengan lokasi penelitian sentra industri batik di Kabupaten Pamekasan. Populasi penelitian ini adalah pemilik UKM batik sebanyak 1.160 unit yang tergabung dalam kelompok sentra industri. Sampel yang digunakan sebanyak 92 responden. Teknik sampling yang digunakan adalah teknik sampling proporsional dan teknik simple random sampling. Variabel Penelitian terdiri dari variabel bebas (Sarana dan prasarana (X1), Perlindungan pemerintah (X2), Pembinaan pemerintah (X3), Asosiasi usaha (X4), Kewirausahaan korporasi (X5), Pengembangan produk (X6), System informasi usaha (X7), Strategi pemasaran (X8), Kemitraan usaha (X9)), dan variabel terikat yaitu Kinerja bisnis (Y). Teknik analisis yang digunakan adalah regresi linear berganda. Hasil analisis menunjukkan bahwa 1). Variabel sarana dan prasarana berpengaruh positif terhadap kinerja bisnis, 2). Variabel perlindungan pemerintah berpengaruh positif terhadap kinerja bisnis, 3). Variabel pembinaan pemerintah berpengaruh negatif terhadap kinerja bisnis, 4). Variabel asosiasi usaha berpengaruh positif terhadap kinerja bisnis, 5). Variabel kewirausahaan korporasi berpengaruh positif terhadap kinerja bisnis, 6). Variabel pengembangan produk berpengaruh positif terhadap kinerja bisnis, 7). Variabel system informasi usaha berpengaruh positif terhadap kinerja bisnis, 8). Variabel strategi pemasaran berpengaruh positif terhadap kinerja bisnis, dan 9). Variabel kemitraan usaha berpengaruh positif terhadap kinerja bisnis.
\end{abstract}

Kata Kunci : Batik, Asosiasi, Pemasaran, Kemitraan, Kinerja. 


\section{PENDAHULUAN}

Permasalahan usaha kecil pada umumnya berkaitan dengan kemampuan manajemen atau pengelolaan yang kurang profesional. Hal ini disebabkan pengetahuan yang dimiliki sangat terbatas. Masalah-masalah ini meliputi, masalah permodalan, produktifitas, personalia, teknologi, daya saing, inovasi dan pemasaran. Permasalahan klasik lainnya dan sangat mendasar yang dihadapi oleh UKM adalah kemampuan untuk bersaing, baik dengan usaha kecil yang sejenis maupun usaha dengan skala yang lebih besar. Ketidakmampuan UKM untuk bersaing, baik di pasar domestik maupun pasar global, dipengaruhi oleh banyak faktor, salah satunya adalah lemahnya akses dan peluang mengembangkan pemasarannya (Depkop, 2010). Kelemahan UKM dalam mengakses pasar dapat berdampak pada sempitnya peluang penjualan. Dugaan kuat, kelemahan UKM didalam mengakses pasar disebabkan karena lemahnya sumber daya manusia yang dimiliki, kemampuan penyediaan permodalan, serta kelemahan untuk membangun jaringan pasar (Hafisah, 2004). Dari faktor eksternal, kelemahan yang dimiliki oleh UKM untuk mengakses pasar masih kurang mendapat perhatian yang serius dari pemerintah. Dampaknya, produk UKM yang sebenarnya memiliki pangsa pasar yang cukup potensial, masih belum banyak diketahui konsumen. Oleh karena itu, solusi penting yang perlu dilakukan oleh UKM untuk mengatasi masalah adalah membuka akses pasar melalui suatu jaringan pemasaran terpadu atau terintegrasi untuk mengenalkan dan mendistribusikan produk-produk yang dihasilkan melalui kerja sama dengan berbagai stakeholder.

Disamping itu, sebagai sebuah usaha mandiri yang mempunyai berbagai keterbatasan, eksistensi dari UKM perlu dukungan penuh dari pemerintah. Hal ini sejalan dengan pendapat yang dikemukakan oleh Hansen yang dikutip oleh Djamhari (2006) bahwa agar pengusaha kecil dapat produktif, sedikitnya diperlukan 3 jenis jaringan interaksi antara jaringan lokal dengan pemerintah, yaitu ; (1) jaringan vertikal, dengan tujuan utama memperbaiki posisi pengusaha di pasar luar daerah (2) jaringan horizontal, meletakkan pengusaha dengan kebutuhan yang sama, bekerja sama dalam pertukaran informasi, teknologi, alat produksi, dan bernegosiasi dengan aparat pemerintah untuk mendapatkan fasilitas umum, seperti infrastruktur dan perijinan, serta; (3) jaringan informasi yang bertujuan untuk meningkatkan pengetahuan, tukar menukar pengalaman dan memperbaiki proses produksi. Dengan kondisi seperti itu, maka UKM 
perlu melakukan komunikasi aktif untuk membangun pemasaran dengan dukungan penuh dari pemerintah sebagai fasilitator. Sebagai sebuah sistemik, UKM yang sudah siap menjalin komunikasi dengan berbagai pihak maka selanjutnya kinerja UKM akan dapat tercapai. Sehingga dalam penelitian ini akan dikaji aspek-aspek yang berkaitan dengan faktor-faktor yang selama ini dianggap berpengauh terhadap kinerja bisnis yang didapatkan dari berbagai lieteratur diantaranya sarana dan prasarana, perlindungan pemerintah, pembinaan pemerintah, asosiasi usaha, kewirausahaan korporasi, pengembangan produk, system informasi usaha, strategi pemasaran dan kemitraan usaha. Aspek-aspek ini akan dijadikan faktor utama dalam menyingkap fenomena peningkatan kinerja bisnis batik.

Mendasarkan pada permasalahan tersebut, maka tujuan penelitian ini adalah untuk menganalisis faktor-faktor yang berpengaruh dalam meningkatkan kinerja bisnis UKM batik Madura.

\section{LITERATUR REVIEW}

\section{UKM dan Pemberdayaan}

Usaha Kecil didefinisikan sebagai kegiatan ekonomi yang dilakukan oleh perseorangan atau rumah tangga maupun suatu badan yang bertujuan untuk memproduksi barang atau jasa untuk diperniagakan secara komersial dan mempunyai omzet penjualan sebesar 1 (satu) miliar rupiah atau kurang (Afiah, 2009). Sementara Usaha Menengah didefinisikan sebagai kegiatan ekonomi yang dilakukan oleh perseorangan atau rumah tangga maupun suatu badan bertujuan untuk memproduksi barang atau jasa untuk diperniagakan secara komersial dan mempunyai omzet penjualan lebih dari 1 (satu) miliar.

Keinginan untuk mempercepat proses pemberdayaan UKM memang tidak mudah karena banyaknya masalah yang membatasi dan menjadi kendala (Suarja, 2007). Oleh karena itu, pemerintah harus berkonsentrasi secara penuh melalui pelaksanaan berbagai program langsung yang bersifat stimulan yang dapat mendorong UKM agar secara mandiri dapat mengatasi permasalahan yang dihadapi. Dari beberapa keterbatasan yang dimiliki oleh UKM, pemerintah sepertinya tidak mungkin memasuki semua aspek, karena pemerintah sebagai unsur penyeimbang hanya mengeluarkan kebijakankebijakan yang pada hakekatnya dapat mendorong pemanfaatan sumberdaya 
pembangunan secara optimal.

Menurut Kuncoro (2000) strategi pemberdayaan yang telah diupayakan selama ini oleh pemerintah dapat diklasifikasikan dalam 1). Aspek managerial, 2). Aspek permodalan, 3). Mengembangkan program kemitraan, 4). Pengembangan sentra industri kecil dalam suatu kawasan, dan 5). Pembinaan untuk bidang usaha dan daerah tertentu lewat KUB.

Hasil penelitian Situmorang (2008) menemukan beberapa upaya yang dapat dilakukan oleh UKM sebagai langkah pemberdayaan, yaitu ; (1) Peningkatan Kualitas SDM, (2) perijinan usaha UKM, (3) peningkatan permodalan, (4) peningkatan kualitas teknologi, dan (5) pengembangan pasar UKM. Sedangkan dari sisi pemerintah sebagai fasilitator, pemberdayaan UKM dapat dilakukan dengan beberapa strategi, yaitu Mempermudah Perolehan Ijin Usaha, Peningkatan Akses Pada Sumber-sumber Permodalan, Pemberdayaan Sumberdaya UKM dan Pengembangan Jaringan Pemasaran.

\section{UKM dan Pemasaran}

UKM masih memiliki kelemahan terutama pada sisi pengembangan pemasaran. Dalam melakukan pemberdayaan UKM, maka harus fokus pada salah satu pemberdayaan agar dapat maksimal. Dalam penelitian ini akan difokuskan pada pengembangan jaringan pemasaran melalui kemitraan dengan jaringan ritel modern. Pengembangan akses dan jaringan pemasaran UKM sampai saat ini masih belum menemukan strategi pemasaran yang sangat tepat. Strategi pemasaran menurut Marrus dalam Umar (2008) merupakan suatu proses penentuan rencana para pemimpin puncak yang berfokus pada tujuan jangka panjang organisasi, disertai penyusunan suatu cara atau upaya bagaimana agar tujuan tersebut dapat dicapai. Sedangkan Prahalad mendefinisikan secara khusus sebagai tindakan yang bersifat incremental (senantiasa meningkat) dan terus-menerus, serta dilakukan berdasarkan sudut pandang tentang apa yang diharapkan oleh para pelanggan di masa depan (Umar, 2008). Menurut Tjiptono (2008), strategi pemasaran merupakan rencana yang menjabarkan ekspektasi perusahaan akan dampak dari berbagai aktivitas atau program pemasaran terhadap permintaan produk atau lini produknya di pasar sasaran tertentu. Program pemasaran meliputi tindakan-tindakan pemasaran yang dapat mempengaruhi permintaan terhadap 
produk, diantaranya dalam hal mengubah harga, memodifikasi kampanye iklan, merancang promosi khusus, menentukan pilihan saluran distribusi, dan sebagainya.

Strategi pemasaran UKM pada dasarnya bertumpu pada 4 bauran pemasaran yaitu strategi pengembangan produk, strategi penentuan harga, strategi penentuan media promosi dan strategi distribusinya sebagaimana dikatakan Kotler dan Armstrong (2008) bauran pemasaran (marketing mix) adalah kumpulan alat pemasaran taktis terkendali yang dipadukan perusahaan untuk menghasilkan respon yang diinginkannya di pasar sasaran.

\section{UKM dan Kinerja Bisnis}

Kinerja bisnis dapat dipahami sebagai media untuk mengukur hasil yang telah dicapai oleh perusahaan selama kurun waktu tertentu. Dari penilaian terhadap kinerja bisnis akan dapat diketahui apakah upaya perbaikan yang selama ini telah dilakukan oleh perusahaan membawa dampak positif bagi perusahaan tersebut. Berbagai perusahaan memiliki cara yang berbeda-beda dalam mengukur kinerja bisnisnya. Namun demikian pengukuran terhadap kinerja ini pada dasarnya dapat digolongkan menjadi dua bagian pokok, yaitu pengukuran terhadap kinerja keuangan (financial) dan pengukuran terhadap kinerja pemasaran (Ferdinand, 2002).

Dalam mengukur kinerja keuangan dapat digunakan dua indikator yaitu Return on assets (ROA) dan Return On Sales (ROS). ROA merupakan perbandingan antara net profit yang diperoleh dengan total asset yang dimiliki perusahaan tersebut. Sedangkan ROS merupakan perbandingan antara net profit yang diperoleh dengan total penjualan yang berhasil dilakukan oleh perusahaan (Farrell, 2000). Pengukuran kedua dilakukan terhadap kinerja pemasaran yang telah diupayakan perusahaan. Ferdinand (2002) menyatakan kinerja pemasaran merupakan faktor yang seringkali digunakan untuk mengukur dampak dari strategi yang diterapkan perusahaan. Strategi perusahaan selalu diarahkan untuk menghasilkan kinerja pemasaran (seperti volume penjualan dan tingkat pertumbuhan penjualan) yang baik dan juga kinerja keuangan yang baik. Strategi pemasaran menurut Tull dan Kahle (1990) dalam Tjiptono (2008) adalah merupakan alat fundamental yang direncanakan untuk mencapai tujuan pemasaran yaitu penjualan yang optimal dengan mengembangkan keunggulan produk untuk bersaing melalui pasar yang dimasuki dan program yang digunakan untuk melayani pasar sasaran . 
Salah satu cara meningkatkan daya saing perusahaan adalah meningkatkan kinerja pemasaran. Aspek pemasaran merupakan posisi strategis. Adanya heterogenitas kekuatan serta kelemahan jaringan pemasaran mendorong para pebisnis untuk melakukan kemitraan, yaitu komplementasi berbagai skill dan sumber daya dari berbagai organisasi sehingga tercipta himpunan kemampuan yang tidak dicapai bila tidak melakukan hal tersebut. Seiring dengan laju perkembangan dalam dunia bisnis yang kian kompetitif, sebuah perusahaan harus mampu membuka pangsa pasar lebih luas. Narver dan Slater (1990) menyatakan bahwa untuk menguasai pasar, perusahaan harus mengelola pasar tersebut dengan upaya - upaya yang sistematis dan terencana dengan baik. Melalui upaya tersebut diharapkan perusahaan memiliki kinerja pasar yang unggul dan mampu meningkatkan keuntungan bagi perusahaan. Berbagai strategi dan program telah diupayakan dalam pemberdayaan UKM. Namun demikian, semua strategi dan program tersebut tidak mungkin dilakukan sendiri oleh pemerintah. Peran dan dukungan masyarakat, perguruan tinggi termasuk para pelaku bisnis dan stakeholders lainnya juga sangatlah penting. Keterbatasan sumberdaya yang dimiliki oleh pemerintah perlu didukung oleh sumberdaya yang lain termasuk oleh para pelaku bisnis itu sendiri (Dipta, 2008). Tanpa ada kemauan dari para pelaku bisnis untuk melakukan perbaikan, bagaimanapun besarnya sumberdaya yang dialokasikan tidak akan dapat mencapai tujuan yang diinginkan. Jadi sinergitas didalam pemberdayaan UKM menjadi kunci penentu dalam rangka membangun UKM yang tangguh dan berdaya saing tinggi di masa depan.

Sebagian besar UKM, berusaha dalam skala usaha yang relatif kecil, dukungan modal terbatas, dan sistem usaha konvensional. Bahkan banyak dari UKM berusaha meneruskan usaha keluarga. Dengan kondisi seperti ini, sangat sulit bagi UKM untuk memperkenalkan produknya kepada pelanggan. Untuk itu umumnya UKM melakukan pemasaran produknya dengan sangat sederhana yaitu dari orang ke orang. Dengan bentuk pemasaran seperti ini peningkatan skala pasar menjadi sangat lambat. Namun demikian kecenderungan ini dapat dinilai positif karena mengindikasikan bahwa sebenarnya UKM sudah menyadari pentingnya membangun jaringan pemasaran dalam memasarkan produk mereka, tetapi kemampuan pemasaran yang ditunjukkan juga sesuai dengan kemampuan usaha mereka.

Berdasarkan hasil studi yang telah dilakukan, UKM yang sering mengikuti 
kegiatan pemasaran produk melalui promosi produknya kebanyakan adalah UKM yang tergolong mempunyai skala usaha kecil menuju menengah (Syarif. 2009). Yang terbanyak dari kelompok ini adalah UKM yang bergerak di sektor industri kerajinan. Umumnya UKM yang bergerak pada sub sektor tersebut belum memahami makna sesungguhnya dari system pemasaran, sehingga adakalanya mereka tidak bisa menilai kelayakan dirinya sendiri untuk membangun jaringan pemasaran.

\section{METODE}

\section{Pendekatan Penelitian}

Penelitian ini menggunakan pendekatan kuantitatif dengan lokasi penelitian sentra industri batik di Kabupaten Pamekasan.

\section{Populasi, Sampel Dan Teknik Sampling}

Populasi penelitian ini adalah pemilik UKM batik sebanyak 1.160 unit yang tergabung dalam kelompok sentra industri. Sampel yang digunakan sebanyak 92 responden berdasarkan perhitungan dengan menggunakan rumus slovin yang merupakan pemilik UKM yang tergabung dalam kelompok sentra industri di kabupaten pamekasan, selanjutnya teknik sampling yang digunakan menggunakan 2 cara yaitu teknik sampling proporsional dan teknik simple random sampling.

\section{Variabel Penelitian}

Variabel bebas :

1. Sarana dan prasarana $\left(X_{1}\right)$

2. Perlindungan pemerintah $\left(\mathrm{X}_{2}\right)$,

3. Pembinaan pemerintah $\left(\mathrm{X}_{3}\right)$,

4. Asosiasi usaha (X4),

5. Kewirausahaan korporasi (X5),

6. Pengembangan produk (X6),

7. System informasi usaha (X7),

8. Strategi pemasaran (X8)

9. Kemitraan usaha (X9), dan

Variabel terikat :

1. Kinerja bisnis (Y). 


\section{Teknik Analisis}

Teknik analisis yang digunakan adalah regresi linear berganda.

\section{Hipotesis}

$\mathrm{H}_{1}$ : Sarana dan prasarana $\left(\mathrm{X}_{1}\right)$ berpengaruh positif terhadap Kinerja bisnis $(\mathrm{Y})$.

$\mathrm{H}_{2}$ : Perlindungan pemerintah $\left(\mathrm{X}_{2}\right)$ berpengaruh positif terhadap Kinerja bisnis $(\mathrm{Y})$.

$\mathrm{H}_{3}$ : Pembinaan pemerintah $\left(\mathrm{X}_{3}\right)$ berpengaruh positif terhadap Kinerja bisnis $(\mathrm{Y})$.

$\mathrm{H}_{4}$ : Asosiasi usaha (X4) berpengaruh positif terhadap Kinerja bisnis (Y).

$\mathrm{H}_{5}$ : Kewirausahaan korporasi (X5) berpengaruh positif terhadap Kinerja bisnis (Y).

$\mathrm{H}_{6}$ : Pengembangan produk (X6) berpengaruh positif terhadap Kinerja bisnis (Y).

$\mathrm{H}_{7}$ : System informasi usaha (X7) berpengaruh positif terhadap Kinerja bisnis (Y).

$\mathrm{H}_{8}$ : Strategi pemasaran (X8) berpengaruh positif terhadap Kinerja bisnis (Y).

$\mathrm{H}_{9}$ : Kemitraan usaha (X9) berpengaruh positif terhadap Kinerja bisnis (Y).

\section{PEMBAHASAN}

\section{Deskripsi Karakteristik Responden}

Penelitian ini dilakukan pada UKM batik di sentra industri batik di kecamatan Proppo 12 sentra (Desa Klampar 5 sentra, Desa Toket dan Candiburung masing-masing 3 sentra dan Desa Rang-perang Daja 1 sentra), Kecamatan palengaan 6 sentra (Desa Banyopelle 2 sentra, Desa Panaan, Angsanah, Akkor dan Larangan Badung masingmasing 1 sentra) dengan jumlah responden sebanyak 92 pemilik usaha. Adapun karakteristik responden yang dianalisis dalam penelitian ini sebagaimana tampak pada Tabel 1berikut :

Tabel 1

\begin{tabular}{|c|c|c|c|}
\hline \multicolumn{5}{|c|}{ Distribusi Karakteristik Responden } \\
\hline Keterangan & Jawaban & Frekuensi & $\mathbf{\%}$ \\
\hline \multirow{3}{*}{ Usia } & $20-30$ tahun & 12 & 13 \\
\cline { 2 - 4 } & $31-40$ tahun & 29 & 32 \\
\cline { 2 - 4 } & $41-50$ tahun & 34 & 37 \\
\cline { 2 - 4 } & $>51$ tahun & 17 & 18 \\
\hline \multirow{3}{*}{ Jenis Kelamin } & Laki- laki & 78 & 85 \\
\cline { 2 - 4 } & Perempuan & 14 & 15 \\
\hline \multirow{3}{*}{ Tingkat Pendidikan } & SLTP & 7 & 57 \\
\cline { 2 - 4 } & SMU & 52 & 30 \\
\cline { 2 - 4 } & Diploma & 5 & 5 \\
\cline { 2 - 4 } & Sarjana & & \\
\hline
\end{tabular}




\begin{tabular}{|c|c|c|c|}
\hline \multirow{2}{*}{ Status Perkawinan } & Belum Menikah & 14 & 15 \\
\cline { 2 - 4 } & Menikah & 78 & 85 \\
\hline
\end{tabular}

Sumber: Data primer diolah

\section{Deskripsi Variabel Penelitian}

Variabel sarana dan prasarana $\left(\mathrm{X}_{1}\right)$ diukur melalui 4 item pertanyaan dan menunjukkan bahwa rata-rata responden memberikan jawaban setuju atau baik (Skor 4) terhadap beberapa pernyataan yang ada pada variabel sarana dan prasarana. Hanya sarana modal yang memiliki nilai cukup baik. Secara keseluruhan rata-rata penilaian responden pada variable ini cukup baik.

Variabel Perlindungan Pemerintah (X2) diukur melalui 3 item pertanyaan dengan nilai rata-rata tanggapan responden cukup setuju terhadap beberapa pernyataan yang diajukan. Secara keseluruhan rata-rata penilaian responden pada variable ini cukup baik.

Variabel Pembinaan Pemerintah (X3) diukur melalui 3 item pertanyaan yang menunjukkan bahwa nilai rata-rata tanggapan responden sangat baik terhadap beberapa pernyataan yang diajukan pada variable ini. Secara keseluruhan rata-rata penilaian responden pada variable ini sangat baik.

Variabel Asosiasi Usaha (X4) diukur dengan 3 item pertanyaan dan nilai rata-rata tanggapan responden sangat baik terhadap beberapa pernyataan yang diajukan pada variable ini. Secara keseluruhan rata-rata penilaian responden pada variable ini sangat baik.

Variabel Kewirausahaan Korporasi (X5) diukur melalui 3 item pertanyaan. Nilai rata-rata tanggapan responden cukup baik terhadap beberapa pernyataan yang diajukan pada variable ini. Secara keseluruhan rata-rata penilaian responden pada variable ini cukup baik.

Variabel Pengembangan Produk (X6) diukur melalui 3 item pertanyaan yang menunjukkan bahwa nilai rata-rata tanggapan responden sangat baik terhadap beberapa pernyataan yang diajukan pada variable ini. Secara keseluruhan rata-rata penilaian responden pada variable ini sangat baik.

Variabel Sistem Informasi Usaha (X7) diukur melalui 3 item pertanyaan. Data menunjukkan bahwa nilai rata-rata tanggapan responden sangat baik terhadap beberapa pernyataan yang diajukan pada variable ini. Secara keseluruhan rata-rata penilaian responden pada variable ini cukup baik. 
Variabel Strategi Pemasaran (X8) diukur melalui 4 item pertanyaan dengan nilai rata-rata tanggapan responden sangat baik terhadap beberapa pernyataan yang diajukan pada variable ini. Secara keseluruhan rata-rata penilaian responden pada variable ini sangat baik.

Variabel Kemitraan Usaha (X9) diukur melalui 8 item pertanyaan. Distribusi nilai rata-rata tanggapan responden cukup baik terhadap beberapa pernyataan yang diajukan pada variable ini. Secara keseluruhan rata-rata penilaian responden pada variable ini cukup baik.

Variabel Kinerja Bisnis (Y) diukur melalui 4 item pertanyaan. Distribusi persentase dari jawaban yang diberikan oleh responden menunjukkan bahwa nilai ratarata tanggapan responden sangat baik terhadap beberapa pernyataan yang diajukan pada variable ini. Secara keseluruhan rata-rata penilaian responden pada variable ini sangat baik.

\section{Uji Validitas dan Reliabilitas}

Hasil uji validitas dengan menggunakan korelasi product moment Pearson dengan pengujian dua arah (two tailed test). Menunukkan bahwa semua nilai peluang lebih kecil dari tingkat signifikan (á) 5\% (0.05). Jadi dapat disimpulkan bahwa pertanyaanpertanyaan sebagai alat ukur untuk mendapatkan data adalah valid yaitu mempunyai derajat keabsahan yang memberikan kontribusi terhadap total score.

Hasil Uji reliabilitas dengan rumus Alpha-Cronbach dengan koefisien alpha sebesar $\geq 0,6$ dihasilkan nilai koefisien alpha lebih besar dari 0,6, maka dapat disimpulkan bahwa seluruh pernyataan dalam kuesioner adalah reliabel (dapat diandalkan).

\section{Uji Regresi Linear Berganda}

\section{Uji Asumsi Klasik}

Hasil uji normalitas data disajikan dalam Gambar 1 berikut ini. 
Normal P-P Plot of Regression Standardized Residual

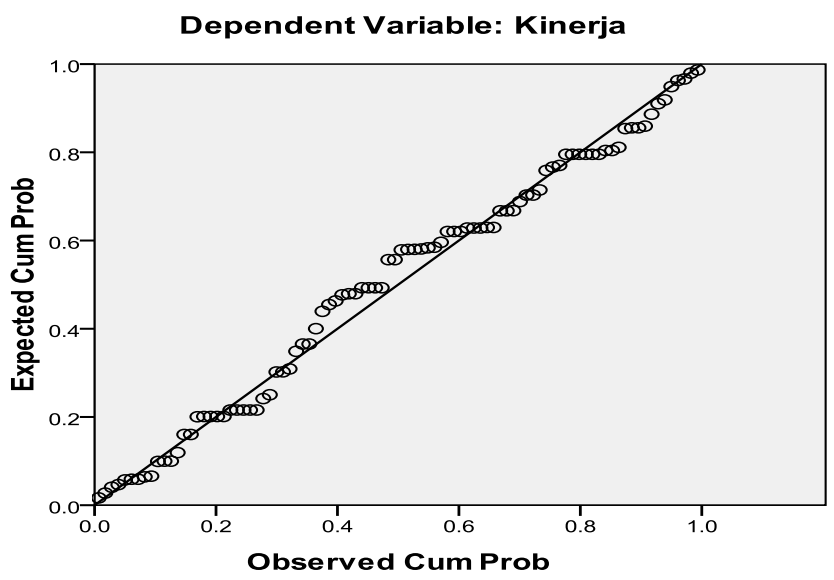

Gambar 1Hasil Uji Normalitas

Sumber: Data primer diolah

Dari tampilan dalam Gambar 1 di atas terlihat bahwa titik-titik menyebar disekitar garis diagonal dan mengikuti arah garis diagonal sehingga dapat disimpulkan bahwa model regresi memenuhi asumsi normalitas.

Hasil pengujian heteroskedastisitas disajikan dalam Gambar 2 berikut ini.

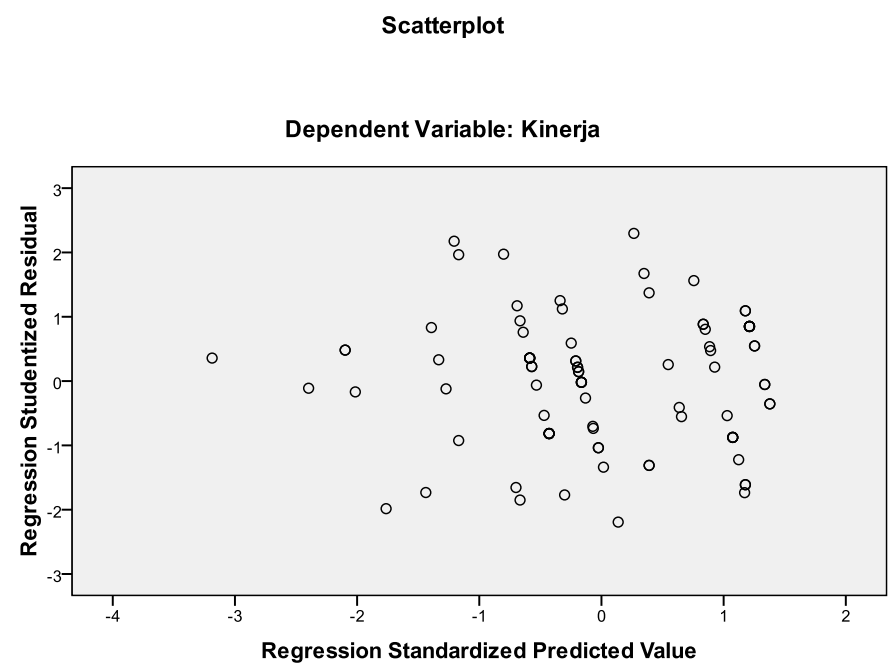

Gambar 2 Hasil Uji Heterokedastisitas

Sumber: Data primer diolah

Dalam Gambar 2 terlihat bahwa titik-titik menyebar secara acak (tidak 
membentuk pola tertentu) serta menyebar baik diatas dan dibawah angka nol sumbu $\mathrm{Y}$ sehingga dapat disimpulkan bahwa tidak terjadi masalah heteroskedastisitas dalam model regresi.

\section{Uji Hipotesis}

Hasil uji hipotesis berdasarkan analisis regresi linear berganda sebagaimana disajikan pada tabel 2 berikut ini.

Tabel 2

Hasil Uji Regresi

\begin{tabular}{|l|c|c|c|c|c|}
\hline \multirow{2}{*}{ Model } & \multicolumn{2}{|c|}{ Unstandardized Coefficients } & \multirow{2}{*}{ Sig. } & Keterangan \\
\cline { 2 - 3 } & $\mathrm{B}$ & Std. Error & & & \\
\hline (Constant) & .736 & .680 & 1.082 & .282 & \\
\hline Sarana dan Prasarana (X1) & .089 & .072 & 1.240 & .219 & H1 Terbukti \\
\hline $\begin{array}{l}\text { Perlindungan Pemerintah } \\
\text { (X2) }\end{array}$ & .160 & .073 & 2.188 & .032 & H2 Terbukti \\
\hline $\begin{array}{l}\text { Pembinaan Pemerintah } \\
\text { (X3) }\end{array}$ & -.412 & .103 & -3.998 & .000 & H3 Tidak \\
\hline Asosiasi Usaha (X4) & .050 & .035 & 1.427 & .157 & H4 Terbukti \\
\hline $\begin{array}{l}\text { Kewirausahaan Korporasi } \\
\text { (X5) }\end{array}$ & .122 & .089 & 1.375 & .173 & H5 Terbukti \\
\hline $\begin{array}{l}\text { Pengembangan Produk } \\
\text { (X6) }\end{array}$ & .045 & .098 & .456 & .649 & H6 Terbukti \\
\hline $\begin{array}{l}\text { Informasi Usaha (X7) } \\
\text { Strategi Pemasaran (X8) }\end{array}$ & .677 & .083 & 8.161 & .000 & H8 Terbukti \\
\hline Kemitraan Usaha (X9) & .111 & .020 & 5.592 & .000 & H9 Terbukti \\
\hline
\end{tabular}

Sumber: Data primer diolah

Berdasarkan hasil pengujian yang dilakukan terhadap variabel penelitian, maka dapat dirumuskan persamaan regresi bergandanya sebagai berikut :

$$
\begin{aligned}
Y= & 0.736+0,089 X_{1}+0,160 X_{2}-0,412 X_{3}+0,050 X_{4}+0,122 X_{5}+0,045 X_{6}+0,117 \\
& X_{7}+0,677 X_{8}+0,111 X_{9}+e
\end{aligned}
$$

Dimana :

$$
\begin{array}{ll}
\mathrm{Y} & =\text { Kinerja Bisnis } \\
\mathrm{X}_{1} & =\text { Sarana dan Prasarana } \\
\mathrm{X}_{2} & =\text { Perlindungan Pemerintah } \\
\mathrm{X}_{3} & =\text { Pembinaan Pemerintah }
\end{array}
$$




$$
\begin{array}{ll}
\mathrm{X}_{4} & =\text { Asosiasi Usaha } \\
\mathrm{X}_{5} & =\text { Kewirausahaan Korporasi } \\
\mathrm{X}_{6} & =\text { Pengembangan Produk } \\
\mathrm{X}_{7} & =\text { Informasi Usaha } \\
\mathrm{X}_{8} & =\text { Strategi Pemasaran } \\
\mathrm{X}_{9} & =\text { Kemitraan Usaha } \\
\mathrm{e} & =\text { Standard error }
\end{array}
$$

Dengan menggunakan persamaan regresi pada model regresi berganda di atas maka dapat diuraikan sebagai berikut :

1. $\beta_{1}=0,089$, dimana nilai ini bertanda positif yang berarti bahwa bila Sarana dan Prasarana ditingkatkan sebesar 0,089, maka kinerja bisnis dari UMKM juga akan meningkat sebesar 0,089. Sehingga hipotesis 1 diterima kebenannya.

2. $\beta_{2}=0,160$, dimana nilai ini bertanda positif yang berarti bahwa bila Perlindungan Pemerintah ditingkatkan sebesar 0,160, maka kinerja bisnis dari UMKM juga akan meningkat sebesar 0,160. Sehingga hipotesis 2 diterima kebenannya.

3. $\beta_{3}=-0,412$, dimana nilai ini bertanda negatif yang berarti bahwa bila Pembinaan Pemerintah diturunkan sebesar 0,412, maka kinerja bisnis dari UMKM juga akan menurun sebesar 0,412. Sehingga hipotesis 3 ditolak kebenannya.

4. $\beta_{4}=0,050$, dimana nilai ini bertanda positif yang berarti bahwa bila Asosiasi Usaha ditingkatkan sebesar 0,050, maka kinerja bisnis dari UMKM juga akan meningkat sebesar 0,050. Sehingga hipotesis 4 diterima kebenannya.

5. $\beta_{5}=0,122$, dimana nilai ini bertanda positif yang berarti bahwa bila Kewirausahaan Korporasi ditingkatkan sebesar 0,122, maka kinerja bisnis dari UMKM juga akan meningkat sebesar 0,122. Sehingga hipotesis 5 diterima kebenannya.

6. $\beta_{6}=0,045$, dimana nilai ini bertanda positif yang berarti bahwa bila Pengembangan Produk ditingkatkan sebesar 0,045, maka kinerja bisnis dari UMKM juga akan meningkat sebesar 0,045. Sehingga hipotesis 6 diterima kebenannya. 
7. $\beta_{7}=0,117$, dimana nilai ini bertanda positif yang berarti bahwa bila Informasi Usaha ditingkatkan sebesar 0,117, maka kinerja bisnis dari UMKM juga akan meningkat sebesar 0,117 . Sehingga hipotesis 7 diterima kebenannya.

8. $\beta_{8}=0,677$, dimana nilai ini bertanda positif yang berarti bahwa bila Strategi Pemasaran ditingkatkan sebesar 0,677, maka kinerja bisnis dari UMKM juga akan meningkat sebesar 0,677. Sehingga hipotesis 8 diterima kebenannya.

9. $\beta_{9}=0,111$, dimana nilai ini bertanda positif yang berarti bahwa bila Kemitraan Usaha ditingkatkan sebesar 0,111, maka kinerja bisnis dari UMKM juga akan meningkat sebesar 0,111. Sehingga hipotesis 9 diterima kebenannya.

Dari hasil penghitungan tersebut dapat disimpulkan bahwa dari Sembilan variabel independen yang diuji pengaruhnya terhadap kinerja bisnis UKM, maka urutan besar pengaruh sebagaimana penjelasan berikut :

1. variabel independen Strategi Pemasaran (X8) merupakan variabel yang paling berpengaruh dengan koefisien regresi sebesar 0.677

2. variabel Perlindungan Pemerintah (X2) dengan koefisien regresi sebesar 0.160

3. variabel Kewirausahaan Korporasi (X5) dengan koefisien regresi sebesar 0.122

4. variabel Informasi Usaha (X7) dengan koefisien regresi sebesar 0.117.

5. variabel Kemitraan Usaha (X9) dengan koefisien regresi sebesar 0.111

6. variabel Sarana dan Prasarana (X1) dengan koefisien regresi sebesar 0.089

7. variabel Asosiasi Usaha (X4) dengan koefisien regresi sebesar 0.050

8. variabel Pengembangan Produk (X6) dengan koefisien regresi sebesar 0.045 dan

9. variabel Pembinaan Pemerintah (X3) dengan koefisien regresi sebesar - 0.412 .

Selanjutnya, besarnya pengaruh secara serempak dari variabel independen terhadap dependent disajikan pada tabel 3 berikut. 
Tabel 3

\begin{tabular}{|c|c|c|c|c|c|}
\hline Model & Sum of Squares & Df & Mean Square & F & Sig. \\
\hline Regression & 650.825 & 9 & 72.314 & 498.165 & $.000^{\mathrm{a}}$ \\
\hline Residual & 11.903 & 82 & .145 & & \\
\hline Total & 662.728 & 91 & & & \\
\hline
\end{tabular}

Sumber: Data primer diolah

Hal ini menunjukkan bahwa variabel independen yang digunakan yaitu variabel sarana dan prasarana $\left(\mathrm{X}_{1}\right)$, perlindungan pemerintah $\left(\mathrm{X}_{2}\right)$, pembinaan pemerintah $\left(\mathrm{X}_{3}\right)$, asosiasi usaha $\left(\mathrm{X}_{4}\right)$, kewirausahaan korporasi $\left(\mathrm{X}_{5}\right)$, pengembangan produk $\left(\mathrm{X}_{6}\right)$, system informasi usaha $\left(\mathrm{X}_{7}\right)$, strategi pemasaran $\left(\mathrm{X}_{8}\right)$ dan kemitraan usaha $\left(\mathrm{X}_{9}\right)$, merupakan variabel yang tepat atau layak untuk menjelaskan terjadinya variasi dalam variabel kinerja usaha kecil.

Sedangkan kemampuan variabel independen dalam menjelaskan variasi yang terjadi dalam variabel dependen ditunjukkan dari hasil penghitungan analisis koefisien determinasi pada tabel 4.

Tabel 4

Hasil Analisis Koefisien Determinasi

\begin{tabular}{|c|c|c|c|c|}
\hline Model & R & R Square & Adjusted R Square & $\begin{array}{c}\text { Std. Error of the } \\
\text { Estimate }\end{array}$ \\
\hline 1 & $.991^{\mathrm{a}}$ & .982 & .980 & .38100 \\
\hline
\end{tabular}

Sumber: Data primer diolah

Koefisien determinasi yang digunakan dalam penelitian ini adalah nilai Adjusted R Square sebesar 0,980. Hal ini menunjukkan bahwa variabel independen yang meliputi variabel sarana dan prasarana $\left(\mathrm{X}_{1}\right)$, perlindungan pemerintah $\left(\mathrm{X}_{2}\right)$, pembinaan pemerintah $\left(\mathrm{X}_{3}\right)$, asosiasi usaha $\left(\mathrm{X}_{4}\right)$, kewirausahaan korporasi $\left(\mathrm{X}_{5}\right)$, pengembangan produk $\left(\mathrm{X}_{6}\right)$, system informasi usaha $\left(\mathrm{X}_{7}\right)$, strategi pemasaran $\left(\mathrm{X}_{8}\right)$ dan kemitraan usaha $\left(\mathrm{X}_{9}\right)$, mampu menjelaskan variasi terjadinya kinerja bisnis yang baik pada UKM sebesar $98 \%$, sedangkan sisanya sebesar $2 \%$ dipengaruhi oleh variabel lain yang tidak diteliti dalam penelitian ini. 


\section{PENUTUP}

1. Variabel sarana dan prasarana $\left(\mathrm{X}_{1}\right)$ berpengaruh positif terhadap kinerja bisnis $(\mathrm{Y})$.

2. Variabel perlindungan pemerintah $\left(\mathrm{X}_{2}\right)$ berpengaruh positif terhadap kinerja bisnis (Y).

3. Variabel pembinaan pemerintah (X3) berpengaruh negatif terhadap kinerja bisnis (Y).

4. Variabel asosiasi usaha (X4) berpengaruh positif terhadap kinerja bisnis (Y).

5. Variabel kewirausahaan korporasi (X5) berpengaruh positif terhadap kinerja bisnis (Y).

6. Variabel pengembangan produk (X6) berpengaruh positif terhadap kinerja bisnis (Y).

7. Variabel system informasi usaha (X7) berpengaruh positif terhadap kinerja bisnis (Y).

8. Variabel strategi pemasaran (X8) berpengaruh positif terhadap kinerja bisnis (Y).

9. Variabel kemitraan usaha (X9) berpengaruh positif terhadap kinerja bisnis (Y).

\section{REFERENSI}

Afiah, Nunuy Nur. 2009. Peran Kewirausahaan Dalam UKM Indonesia Menghadapi Krisis Global, Working Paper In Accounting, Center For Accounting Development Department Of Accounting, Padjajaran University.

Arikunto, Suharsini. 1998. Prosedur Penelitian, Suatu Pendekatan Praktik, PT. Bina Aksara, Jakarta.

Dipta, I. Wayan. 2008. Strategi Penguatan Usaha Mikro, Kecil Dan Menengah (UKM) Melalui Kerjasama Kemitraan Pola CSR, Infokop Vol. 16.

Dirjen Pemerintahan Umum Departemen Dalam Negeri. 2009.

Djamhari, Choirul. 2006. Faktor-Faktor Yang Mempengaruhi Perkembangan Sentra UKM Menjadi Klaster Dinamis, Infokop Nomor 29 Tahun XXII.

Effendi, Ishak. 2005. Peranan Informasi Bagi Kemajuan UKM. Artikel. Kedaulatan Rakyat, Yogyakarta.

Eva, Fathor dkk. 2011. Kajian Model Kemitraan Kelompok Petani Tembakau Di Kabupaten Sumenep

Farrel, Mark A. 2000. Developing a Marked Oriented Learning Organization. Australian Journal of Management, Vol. 25, No. 2

Fathor. A.S dan Arief. 2009. Analisis SWOT dan Kebijakan Pengembangan Usaha Mikro dan Home Industry di Pamekasan. P2M FE Universitas Trunojoyo.

2012. Model Pemberdayaan UKM Melalui Intensifikasi Dan Integrasi Sistem Komunikasi Sebagai Dasar Untuk Mempercepat Penguatan 
Pada Kelompok Sentra Di Kabupaten Bangkalan

Ferdinand, Augusty. 2002. Marketing Strategy Making : Proses dan Agenda Penelitian”. Jurnal Sains Pemasaran Indonesia, Vol. I, No. 1 (Mei), pp : 1-22.

Hafizah, Evi. 2003. Strategi Penguatan Usaha Mikro, Kecil Dan Menengah (UKM) Melalui Kerjasama Kemitraan Pola CSR. Agrisep Vol. 2 No. 1.

Kotler, Philip dan Gary Armstrong. 2008. Prinsip-Prinsip Pemasaran, Penerbit Erlangga, Jakarta.

Kuncoro, Mudrajad. 2000. The Economics of Industrial Agglomeration and Clustering, 1976-1996: the Case of Indonesia (Java), disertasi Ph.D, Department of Management, University of Melbourne, Melbourne.

---------. 2000. Usaha Kecil Di Indonesia: Profil, Masalah Dan Strategi Pemberdayaan. Makalah Studium Generale di STIE Kerja Sama, Yogyakarta, 18 Nopember 2000.

Narver, J.C. dan Stanley F. Slater. 1990. The Effect of Market Orientattion on Business Provitability, Journal of Marketing , 36, January

Porter, Michel E. 1993. Keunggulan Bersaing : Menciptakan dan Mempertahankan Kinerja Urtggul, terjemahan, Penerbit Erlangga, Jakarta.

Porter, Michael. 2000. Location, Clusters and Company Strategy, Oxford University Press.

Rahardjo, Budi. 2006. Cybercity, Klaster Industri dan Inovasi, Bulletin ITPIN.

Scorsone, Industrial Clusters : Enhancing economics through business linkage, SRDC Publication.

Shipley, David dan Colin Egan, 1992. Power, Conflict and Co-operation inBeetwerTenant Distribution Channels, internatinal Journal of Service Industry Management, Vol 3.No.4 pp 44-62

Situmorang, Jannes. 2008. Strategi UKM Dalam Menghadapi Iklim Usaha Yang Tidak Kondusif. Infokop Volume 16.

Suarja, W. 2007. Prospek Pengembangan Kredit Usaha Rakyat dalam Mendukung Pemberdayaan UKM dan Koperasi, Harian Media Indonesia, Jakarta

Soetrisno, Noer. 2001. Science and Technology Policy and Strategy For Establishing ST Business Program : The Indonesia's SME Perspective, The International Journal of IIFTIHAR, January 2001.

Syarif, Teuku. 2009. Kajian Efektifitas Model Promosi Pemasaran Produk UKM, publikasi.

Tambunan, Tulus. 2010. Ukuran Daya Saing Koperasi Dan UKM, Background Study RPJM Nasional Tahun 2010-2014 Bidang Pemberdayaan Koperasi dan UKM, Bappenas.

Thoreli, Hans B, (1996)." Network : Between Markets and Herarchies." Strategic Management journal $7: 37-51$

Tjiptono, Fandy (2008). Strategi Pemasaran, Penerbit ANDI, Yogyakarta.

Umar, Husein, 2003, Metode Riset Perilaku Konsumen Jasa, Ghalia Indonesia, 
Jakarta.

2008. Strategic Management in Action; Konsep, Teori dan Teknik Menganalisis Manajemen Strategis. Gramedia Pustaka Utama, Jakarta.

Undang-Undang Nomor 20 Tahun 2008 tentang Usaha Mikro, Kecil dan Menengah www.depkop.go.id. 15 Januari 2010.

www.http://disperindag.pamekasankab.go.id/?page_id=113.

www. Jawa Pos, Senin, 19 Feb 2007

www ml.scribd.com/doc/80248247/Makalah-PDKM-Memasok-Ritel-Besar. 